\title{
Investigating the Role of Management Ownership in Revealing Firm Value
}

\author{
Deddy Mendai Zuhriansyah ${ }^{1}$, Aprih Santoso ${ }^{2}$ \\ 1,2 Universitas Semarang, Indonesia \\ Qaprihsantoso@usm.ac.id
}

\begin{tabular}{|c|c|}
\hline & ABSTRACT \\
\hline & $\begin{array}{l}\text { This study aims to analyze the role of management ownership in } \\
\text { moderating the effect of total asset turnover on firm value. The data is }\end{array}$ \\
\hline $\begin{array}{l}\text { ARTICLE INFO } \\
\text { Article history: }\end{array}$ & taken from the financial statements and annual reports of manufacturing \\
\hline Received & ange for the period $2017-$ \\
\hline June 06, 2021 & sing purposive sampling, $27 \mathrm{cc}$ \\
\hline $\begin{array}{l}\text { Revised } \\
\text { July } 02,2021\end{array}$ & the help of the IBM SPSS Statistic 25 application. The results showed that \\
\hline Accepted & effect on firm value. The results of testing the \\
\hline July 05, 2021 & $\begin{array}{l}\text { moderating variable show that management ownership does not } \\
\text { moderate the effect of TATO on firm value. }\end{array}$ \\
\hline
\end{tabular}

How to cite

Keywords: Management Ownership, Firm Value, The Role of Management

Zuhriansyah, D, \& Santoso, A.,(2021). Investigating the Role of Management Ownership in Revealing Firm Value. IJoASER (International Journal on Advanced Science, Education, and Religion), 4(2). 100-109.

https://doi.org/10.33648/ijoaser.v4i2.110

Journal Homepage https://ojs.staialfurqan.ac.id/IJoASER/

This is an open access article under the CC BY SA license

https://creativecommons.org/licenses/by-sa/4.0/

\section{INTRODUCTION}

The value of the company is very important because the goal of the company is to increase the value of the company which will have an impact on increasing the prosperity of the owners of capital (Nafisa, et al 2018). Firm value is a reflection of every management's financial actions and decisions that affect stock market prices. Firm value is an investor's perception of the company, which is often associated with stock prices (Sadalia, et al, 2017).

Total asset Turnover (TATO) is an activity ratio which is a comparison between sales and total assets. The higher the Total Asset Turnover (TATO) indicates the more effective asset management in generating sales for the company. Alivia (2013), Rinnaya et al (2016), Misran \& Chabachi (2017), Sugiarto \& Santosa (2017), Aprilia et al (2018), Kusumawati \& Rosady (2018) stated that Total Asset Turnover (TATO) had a positive and significant effect on firm value, while Utami \& Prasetiono (2016), Sutrisno \& Yulianeu (2017), Nafisa, et al (2018) stated that Total Asset Turnover (TATO) had no significant effect on firm value, and Nazariah et al (2019) shows that TATO has a negative and significant effect on firm value. Another result, Stiyarini \& Santoso (2016) actually states that TATO has an effect but is not significant on firm value.

There is a business phenomenon related to the increase and decrease in the average value of Total Asset Turnover (TATO) which is not followed by an increase and decrease in the average value of firm value in manufacturing companies listed on 
the Indonesia Stock Exchange for the 2017-2019 period. as shown in table 1 the following:

Tabel 1. Business Phenomenon

\begin{tabular}{|c|c|c|c|}
\hline Variable & 2017 & 2018 & 2019 \\
\hline TATO & 0,987 & 1,003 & 0,964 \\
\hline Firm Value & 1,924 & 2,021 & 1,833 \\
\hline
\end{tabular}

TATO average on in 2017 was 0.987 increased to 0.970 in 2018, and decreased again to 0.964 in 2019. On the other hand, the average company value in 2017 was 1,924 then in 2018 it increased to 2,021 and then in 2019 drops to 1,833. Firm value in the last year has decreased as a result of a decrease in sales even though it has increased in the previous year so it is necessary to investigate the cause.

Taking into account various previous studies, there are differences in research results on the effect Total Asset Turnover (TATO) on firm value. Management ownership as a component of good corporate governance is expected to be able to overcome agency problems in the company. For this reason, management ownership is suspected to be a control over the value of the company considering that it can strengthen or weaken the effect of Total Asset Turnover (TATO).

Manufacturing companies are sampled in this study considering the number of companies that fall into the dominant category of all company sectors in Indonesia, this is able to provide freedom for the number of researched, where the more objects studied, the better the results.

\section{LITERATUR REIVEW}

Agency Theory (Agency Theory)

Husnan \& Pudjiastuti (2015), stated that in general in large companies there is often a separation between company managers, namely the management is referred to as the agent with the company owner or shareholders commonly referred to as the principal. This can allow the emergence of agency problems (Agency problems). Agency problems arise in two forms, namely between company owners and management, and between shareholders and bondholders. The normative purpose of financial decision making, which states that decisions are taken to maximize the wealth of the owners, is not always true, because it is possible that management makes decisions that are best for the benefit of management, not for the owners of the company.

\section{Firm value}

Firm value indicates a profit obtained by investors when the company purchased through the stock mechanism is offered by other potential investors at a relatively high price. This is in line with the theory of the firm, namely prosperous investors. Hermuningsih et al (2010) revealed that the greater the Price Book Value (PBV), the higher the company is valued by investors relative to the funds invested in the company.

\section{Total Asset Turnover}

Factors that affect firm value include the activity ratio. The activity ratio shows how resources have been utilized optimally within the company (Martiani \& Purbawangsa, 2018). In this study, the activity ratio used is TATO (Total Asset Turnover). The company carries out its main activity to earn income, using assets in the form of assets. Total Assets Turnover is a measure of the overall turnover of all assets. 
This ratio shows the ability of the company's assets to generate total net sales. The higher the ratio of sales to total assets indicates the more effective the company in the use of its assets to generate total sales. The more effectively the company uses its assets to generate sales, the better the performance achieved by the company. This study examines the effect of total assets turnover on firm value (Prihadi, 2010).

\section{Management Ownership}

The separation of ownership and control arises in modern companies as a result of several conflicts of interest between company management and shareholders. However, when ownership is dispersed among many individuals, the company's resources may be used by managers to their advantage rather than considering the shareholder wealth maximization objective. Salvatore (2011) reveals that agency problems will arise if managers and shareholders have different goals.

Managers who have the responsibility to optimize the profits of the owners of capital, on the other hand also have an interest in maximizing their own welfare. Shareholders can be divided into two major groups, namely: Shareholders who are also part of the company's management (insider shareholders) and shareholders who are not part of the company's management (outsider shareholders). Samisi \& Ardiana (2013) stated that the separation of the management function and the ownership function in the company can trigger agency conflicts within the company. Management ownership will be able to match the interests between management and the interests of shareholders. The increasing share ownership by management will cause management to be more careful in using the company in running the company because they share the risks arising from these actions.

Kusumawati \& Rosady (2018) revealed that share ownership by the management is one of the actions that can be taken to overcome agency conflicts between various existing interest groups. Company owners can compensate managers in the form of share ownership so that managers think to always increase the value of the company which means also optimizing the welfare of shareholders. This is in line with what was expressed by Rizqia, et al (2013) which states that managerial ownership can reduce agency problems. Managerial ownership can reduce the desire of managers to act that is detrimental to the company.

\section{Effect of Total Asset Turnover (TATO) on Firm Value}

Total Asset Turnover (TATO) shows the ability of the company's assets to generate total net sales. The higher the Total Asset Turnover (TATO), the more effective the company is in using its assets to generate total net sales. Misran \& Chabachib (2017) who tested the effect of Total Asset Turnover (TATO) on firm value obtained research results which showed that Total Asset Turnover (TATO) had a positive and significant effect on firm value. The more effectively the company uses assets to generate net sales, the higher the value achieved by the company, this is supported by the results of research by Misran \& Chabachib (2017) which states that Total Asset Turnover (TATO) has a positive and significant effect on firm value.

Based on the description above, it is known that Total Asset Turnover (TATO) is the ability of the company's assets to generate total net sales. A high tattoo indicates the company's effectiveness in using assets to generate sales, so that it can give a positive signal to investors who can increase the value of the company, it can be formulated into the fourth hypothesis as follows:

H1: Total Asset Turnover (TATO) has a positive effect on firm value. 


\section{Management Ownership Moderates The Effect of Total Asset Turnover (TATO) on Firm Value}

Management, who is also the owner of the company's shares, will act more carefully in every activity and decision it makes. Management Ownership can direct the company's policy to increase Total Asset Turnover (TATO) so as to increase the firm value. PrahiawanMisran \& Chabachib (2017) which tested the effect of Total Asset Turnover (TATO) on firm value where the research results showed that Total Asset Turnover (TATO) had a positive and significant effect on firm value. The higher management ownership can increase the value of the company. Based on this description, it can be formulated into hypothesis 2 as follows: H2: Management Ownership strengthens the effect of Total Asset Turnover (TATO) on firm value

\section{METHOD}

\section{Data Types and Sources}

The type of data used in this research is secondary data. The data sources of each variable used are TATO, management ownership and firm value obtained from financial reports on the Indonesia Stock Exchange for the period 2017-2019.

\section{Population and Sample}

The population that is the object of this study is all manufacturing companies whose shares are listed on the IDX since 2017-2019. Meanwhile, the number of manufacturing companies listed on the IDX in that period was 184 companies. The reason for choosing the manufacturing sector is because it is the largest sector on the Indonesia Stock Exchange, while the reason for choosing the 2017-2019 period is because it is the newest one so that the results will be better. Collecting data in this study using the method of merging or pooling data (time series and cross-sectional). Data pooling is done by adding up the companies that meet the research criteria in the three-year period of the study, namely 2017 - 2019. The advantage of collecting samples by pooling data is that by obtaining a larger number of samples, it is expected to increase the power of test in this study. The sampling technique in this study used purposive sampling with the following criteria: (1) Manufacturing companies listed on the Indonesia Stock Exchange in 2017-2019. (2) Manufacturing companies with share ownership composition, owned by management within the company with a total of more than 1\% of all outstanding shares, during the 2017-2019 period.

Method of collecting data

Data collection is based on secondary data documentation techniques by recording data originating from the financial statements of companies listed on the Indonesia Stock Exchange through the IDX website at the address www.idx.co.id. The data used are financial reports for the three-year period of the study, namely 2017 2019.

\section{Operational Definition and Measurement of Variables Total Asset Turnover (TATO)}

TATO is the ability of the company's assets to generate total net sales. This ratio measures the efficiency of using all assets in making sales

\section{Management Ownership}

Management ownership is the shareholder of the management who actively participates in making company decisions, including Managers, Directors, and Commissioners. 


\section{Firm Value}

Firm value is the price that prospective buyers are willing to pay if the company is sold. Firm value is proxied through price to book value (PBV).

\section{Regression Equation}

This study is to examine the magnitude of the effect of TATO on firm value. Apart from that, there is a management ownership variable to determine the moderating effect on the relationship between the independent variable and the dependent variable. To see the effect of moderation by using the absolute difference value equation model. To see the type of moderation, two equation models are used, so that the regression model equation becomes as follows:

Equation 1 :

$\mathrm{FV}=\alpha+\beta 1 \mathrm{TATO}+\beta_{2} \mathrm{MO}+\mathrm{e}$

Equation 2:

$\mathrm{FV}=\alpha+\beta_{1} \mathrm{X} 1+\beta_{2} \mathrm{MO}+\beta_{3}(\mathrm{ABSTATO} * \mathrm{MO})+\mathrm{e}$

Information:

TATO Independent Variable $=$ Total Assets Turn Over

MO Moderation Variable = Management Ownership

Dependent Variable FV = Firm Value

a $\quad=$ constant variable

e $\quad=$ Standard error

Where, (ABSTATO*MO) is the interaction value measured by the difference between the absolute values of TATO and MO,

\section{RESULT AND DISCUSSION}

Descriptive statistics

Based on raw data inputted from the financial statements of manufacturing companies listed on the Indonesia Stock Exchange for the 2017-2019 period, TATO, firm value and management ownership can be calculated. Furthermore, the minimum, maximum, average (mean) and standard deviation of each research variable can be seen in table 2 below:

Table 2. Descriptive Statistics

\begin{tabular}{lrrrrr}
\hline & & \multicolumn{2}{c}{ Maximu } & Std. \\
& $\mathrm{N}$ & Minimum & \multicolumn{1}{c}{$\mathrm{m}$} & \multicolumn{1}{c}{ Mean } & Deviation \\
\hline TATO & 81 & .2871 & 2.0958 & 1.049839 & .4158187 \\
MO & 81 & .0102 & .7000 & .158878 & .1726837 \\
FV & 81 & .1973 & 7.2883 & 1.951530 & 1.6870349 \\
Valid N (listwise) & 81 & & & & \\
\hline
\end{tabular}

\section{Total Asset Turnover}

The results of the descriptive statistical test presented in table 4.1 show that the minimum value is 0.2871 (PT. Aneka Gas Industri Tbk, 2017) and the maximum value is 2.0958 (PT. Buyung Poetra Sembada Tbk, 2017) and the average is 1.0498 with a standard deviation of 0.4158 . The standard deviation is smaller than the average value, this indicates a good thing because the deviation is smaller than the average value, so the Total Asset Turnover data can be said to be good. 


\section{Management Ownership}

The results of the descriptive statistical test presented in table 4.1 show that the minimum value is 0.0102 (PT. Indal Aluminum Industry Tbk, 2019) and the maximum value is 0.7000 (PT. Sad Nusapersada Tbk, 2019) and the average is $0 . .1588$ with a standard deviation of 0.1726 . A standard deviation greater than the average value means that the data distribution is more diverse or the data deviation is relatively large. The standard deviation value that reflects the deviation from the variable data is relatively higher because it is greater than the average value. This shows that the Ownership Management data is said to be not good enough.

\section{Firm Value}

The results of the descriptive statistical test presented in table 4.1 show that the minimum value is 0.1973 (PT. Indal Aluminum Industry Tbk, 2017) and the maximum value is 7.288 (PT. Mark Dynamics Indonesia Tbk, 2017) and an average of 1, 9515 with a standard deviation of 1.6870. The standard deviation is smaller than the average value, this indicates a good thing because the deviation is smaller than the average value, so firm Value data can be said to be good.

\section{Data Analysis}

Hypothesis testing is done by t-test to show how far the influence of one independent variable individually in explaining the dependent variable.

\section{First Equation}

Based on the results of SPSS output, it can be seen that the partial effect of TATO on firm value is shown in table 3 as follows:

Table 3 Partial Regression of the First Equation

\section{Coefficients $^{\text {a }}$}

\begin{tabular}{|c|c|c|c|c|c|c|}
\hline \multirow[b]{2}{*}{ Mode } & & \multicolumn{2}{|c|}{$\begin{array}{c}\text { Unstandardized } \\
\text { Coefficients }\end{array}$} & $\begin{array}{c}\text { Standardized } \\
\text { Coefficients }\end{array}$ & \multirow[b]{2}{*}{$t$} & \multirow[b]{2}{*}{ Sig. } \\
\hline & & $\mathrm{B}$ & Std. Error & Beta & & \\
\hline \multirow[t]{3}{*}{1} & (Constant) & 1.005 & .203 & & 4.948 & .000 \\
\hline & TATO & .383 & .202 & .178 & 1.896 & .062 \\
\hline & $\mathrm{MO}$ & .064 & .072 & .079 & .893 & .375 \\
\hline
\end{tabular}

a. Dependent Variable: FV

\section{Second equation}

Based on the results of SPSS output, it can be seen that the moderation of management ownership on the interaction between the independent variables of profitability, liquidity, leverage and TATO on firm value as shown in table 4 below: 
Table 4. Partial Regression Second equation

Coefficients $^{\mathrm{a}}$

\begin{tabular}{|c|c|c|c|c|c|c|}
\hline \multirow[b]{2}{*}{ Model } & & \multicolumn{2}{|c|}{$\begin{array}{c}\text { Unstandardized } \\
\text { Coefficients }\end{array}$} & $\begin{array}{c}\text { Standardized } \\
\text { Coefficients }\end{array}$ & \multirow[b]{2}{*}{$\mathrm{t}$} & \multirow[b]{2}{*}{ Sig. } \\
\hline & & $\mathrm{B}$ & Std. Error & Beta & & \\
\hline 1 & (Constant) & .115 & .136 & & .843 & .402 \\
\hline & Zscore(TATO) & .130 & .069 & .176 & 1.900 & .062 \\
\hline & Zscore(MO) & .068 & .067 & .093 & 1.023 & .310 \\
\hline & $\begin{array}{l}\text { ABSTATO*M } \\
\mathrm{O}\end{array}$ & .076 & .081 & .091 & .938 & .351 \\
\hline
\end{tabular}

a. Dependent Variable: FV

\section{The Effect of Tattoos on firm Value}

Based on the partial test calculation of the first equation, the t-count value is 1.896 $<\mathrm{t}$-table 1.992, and the significance value is $0.062>0.05$, the value of 1 unstandardized coefficients is 0.383 the regression coefficient is positive, then the hypothesis $(\mathrm{H} 0)$ is accepted and $(\mathrm{Ha})$ rejected, so that it can be concluded that TATO has no effect on firm value. So the fourth hypothesis, $\mathrm{H} 1$ which states that total asset turnover has a positive effect on firm value, is proven to be rejected.

High company asset turnover can indicate good company performance, if it is marked by increasing company profits, so that it has an impact on increasing returns to be obtained by investors. On the other hand, a high turnover of company assets that is not accompanied by a high increase in profit can be an indication that managers are not working effectively and efficiently so that high sales do not have an impact on the maximum profits obtained by the company. This research supports of Nafisa, et al (2018) stated that Total Asset Turnover (TATO) had no significant effect on firm value and Nazariah et al (2019) shows that TATO has a negative and significant effect on firm value. The results of this study are not in line with Misran \& Chabachi (2017), Kusumawati \& Rosady (2018) who concluded that total asset turnover has a positive and significant effect on firm value. Another result, Stiyarini \& Santoso (2016) actually states that TATO has an effect but is not significant on firm value.

Management Ownership Moderates The Effect of TATO on Firm Value

Based on the partial test calculation of the second equation, the $\mathrm{t}$-count value is $0.938<$ t-table 1.994, and the significance value is $0.351>0.05$, the value of 1 unstandardized coefficients is 0.076 the regression coefficient is positive. Then the hypothesis (H0) is accepted and (Ha) is rejected, so that it can be concluded that management ownership is not able to moderate the effect of TATO on firm value. So it is known that management ownership is not a moderating variable in the interaction between TATO and firm value. So the eighth hypothesis, $\mathrm{H} 2$ which states that management ownership strengthens the effect of TATO on firm value, is proven to be rejected.

Management Ownership can reduce the desire of managers to act that is detrimental to the company. management Ownership can encourage management who is also the owner of the company to increase its main activity in obtaining income, by using facilities in the form of assets that can be measured by the TATO activity ratio. An increase in TATO that is not supported by a high increase in profit can be an indication that the manager is not working effectively and efficiently because high sales do not have an impact on the maximum profit earned by the company. Investors 
do not attach importance to the company's ability to generate sales volume based on the assets owned by the company, because for investors one of the important things to pay attention to is how the company's performance in obtaining profits.

In this study, it turns out that management ownership is not a moderating variable in the interaction relationship between TATO and firm value. The relationship between TATO and the firm value of the manufacturing is a non-unidirectional relationship, if the asset turnover is low, the company value will actually increase, and vice versa.

The results of this study are not in line with the results of Syafitri's (2015) research. the greater the management ownership, the more efficient the utilization of manufacturing company assets, so that management ownership can monitor the management of the manufacturing company's activities.

The practical contradiction of this research is that research on company tattoos on the value of the manufacturing sector company is expected to be used as consideration for investors to analyze and determine the right investment choices, so that investors can minimize the risk of their investment and optimize the profits to be achieved. In addition, it can be used as a basis for research and consideration for decision makers (executives) in the future and can also be used as motivation by management to improve management performance so that it can be reflected in company values.

\section{CONCLUSIONS}

Based on the results of the research conducted, it was found that TATO does not affect the value of the company, this means that increasing the value of TATO does not significantly increase the value of the company. Management ownership is proven not to moderate the effect of TATO on firm value, this means that the effect of TATO on firm value is not significantly strengthened by the interaction of management ownership variables so that it is known that management ownership is not a moderating variable in the interaction between TATO and firm value. The results of this study contradict the research of Misran \& Chabachib (2017) which states that TATO has a positive and significant effect on firm value. Managerial implication that can be carried out by management in an effort to increase the firm value. In order to achieve the company's goal to prosper its owners, managers must be able to build an effective and efficient company system, so that increasing the company's ability to generate sales volume can also be accompanied by maximum profits. With management ownership in the company, making management the manager of the company, as well as the owner of the company, will certainly reduce conflicts of interest and encourage the realization of a Good Corporate Governance mechanism. Management ownership is expected to encourage the creation of efficiency and effectiveness in every company activity, as well as decision making that is oriented to the best interests of the company, so that management ownership will have a positive effect on the company's performance in achieving the goals for the prosperity of the owners of capital.

\section{AUTHOR CONTRIBUTION STATEMENT}

The first author has contributed in the collection and analysis of research data. The second author is the person who corresponds with the editor, from submitting revisions to publishing articles. 


\section{ACKNOQLDEGMENT}

We express our gratitude and appreciation for the support that has been given by the University of Semarang and the management of the ijoaser journal.

\section{REFERENCES}

Alivia, N.R. (2013). “Analisis Faktor-faktor yang Mempengaruhi Nilai Perusahan dengan Profitabilitas sebagai variabel Invervening (Studi pada Perusahaan Manufaktur yang Listed di BEI)". Jurnal Manajemen Universitas Diponegoro. 2(2): $1-12$

Aprilia, RSR., Puspitaningtyas, Z. \& Prakoso, A. (2018). Pengaruh Current Ratio, Total Asset Turnover Dan Debt To Equity Ratio Terhadap Price To Book Value Dengan Return On Asset Sebagai Variabel Intervening (Studi Pada Perusahaan Sektor Industri Barang Konsumsi di Bursa Efek Indonesia Periode 2013-2017). Jurnal Profita. 11(2). 1-26

Hermuningsih, Sri. Harjito D.A. \& Wardani D.K. (2010). The influence of insider ownership, deviden policy, and debt policy to the firm value at companies which are enlisted in Indonesia Stock Exchange. ICBE 2010. http://repo.unand.ac.id/id/eprint/5090

Husnan, S. \& Pudjiastuti, E. (2015). Dasar-dasar manajemen keuangan. Edisi 7, UPP STIM YKPN, Yogyakarta.

Kusumawati, R. \& Rosady, I,. (2018). Pengaruh sturuktur modal dan profitabilitas terhadap nilai perusahaan dengan kepemilikan manajerial sebagai variabel moderasi. Jurnal Manajemen Bisnis. 9(2). 147-160

Martiani, NMA. \& Purbawangsa, IBA. (2018). Peran Kepemilikan Isntitusional Dalam Memoderasi Pengaruh Leverage, Likuiditas Dan Aktivitas Terhadap Profitabilitas. E-Jurnal Manajemen Unud, 7(4). 2256-2288

Misran M, \& Chabachib M. (2017). Analisis pengaruh DER, CR, dan TATO terhadap PBV dengan ROA sebagai variabel intervening (Studi pada perusahaan properti dan real estate yang terdaftar di BEI tahun 2011 - 2014). Dipenogoro Journal of Management, 6(1). 1-13

Nafisah, Izatun N., Halim, A., \& Sari, A.R. (2018). Pengaruh return on assets (ROA), debt to equity ratio (DER), current ratio (CR), return on equity (ROE), price earning ratio (PER), total assets turnover (TATO), dan earning per share (EPS) terhadap nilai perusahaan manufaktur yang terdaftar di BEI tahun 2014-2015. Jurnal Riset Mahasiswa Akuntansi, JRMA. 6(2). 1-17

Nazariah, Maisur \& Masytari. A. (2019). Pengaruh rasio keuangan terhadap nilai perusahaan (Perusahaan manufaktur sektor industri barang konsumsi yang terdaftar di BEI tahun 2013-2017). Jurnal Real Riset. 1(2). 61- 69

Prihadi, T (2010). Analisis laporan keuangan teori dan aplikasi. Cetakan-1, PPM, Jakarta.

Rinnaya, IY. Andini, R. \& Oemar, A. (2016). Pengaruh Profitabilitas, Rasio Aktivitas, Keputusan Pendanaan Keputusan Investasi Terhadap Nilai Perusahaan (Studi Empiris Pada Perusahaan Manufaktur Yang Terdaftar Di BEI Tahun 2010-2014). Journal Of Accounting, 2(2). 1-18

Sadalia, Simanjuntak I.,S., \& Butar-Butar N.A. (2017). An analysis of the determinants of capital structure and their influence on firm value (a case study on manufacturing companies investors in Southeast Asia). International Journal of Applied Business and Economic Research. 16(19). 165-177

Salvator, D. (2011). Managerial economics, ekonomi manajerial dalam perekonomian global. Buku 1, Edisi Kelima, Cengage Learning Asia Ptd Ltd and Salemba Empat, 
Jakarta.

Samisi, K. \& Ardiana A. (2013). Pengaruh struktur pendanaan terhadap nilai perusahaan dengan kepemilikan manajerial sebagai variabel moderasi. EJurnal Akuntansi. 5(2). 451-469.

Stiyarini \& Santoso, BH. (2016). Pengaruh kinerja keuangan terhadap nilai perusahaan pada perusahaan jasa telekomunikasi. Jurnal Ilmu dan Riset Manajemen. 5(2). 1-21

Sugiarto, M \& Santosa, PW. (2017). Pengaruh Indikator Makro Ekonomi, Kinerja Keuangan, Dan Tata Kelola Terhadap Nilai Perusahaan Pada Sektor Properti Di Bursa Efek Indonesia. Journal of Economics and Business Aseanomics (JEBA). 2(2). 288-312

Sutrisno, W.A. \& Yulianeu. (2017). Pengaruh CR, DER, dan TATO Terhadap PBV dengan ROA sebagai variabel intervening (Studi pada Perusahaan Property dan Real Estate Real Estate yang terdaftar pada BEI Tahun 2010-2014). Journal of Management. 3(3). 1-8.

Syafitri, Lili. (2015). Pengaruh Inventory Turnover dan Total Asset Turnover Terhadap Profitabilitas Pada CV. Teluk Kenanga Ogan Ilir. Jurnal Ilmiah STIE MDP, 4 (2):74-83

Utami, R.B. \& Prasetiono. (2016). Analisis Pengaruh TATP, WCTO, dan DER Terhadap Nilai Perusahaan dengan ROA sebagai Variabel Intervening (Studi pada Perusahaan Manufaktur yang Terdaftar di Bursa Efek Indonesia Periode Tahun 2009-2013). Jurnal Studi Manajemen dan Organisasi. 12(1). 28-43.

\section{Copyright Holder :}

(C) Zuhriansyah, D, \& Santoso, A.,(2021).

First Publication Right :

(c) IJoASER (International Journal on Advanced Science, Education, and Religion)

This article is under:

CC BY SA 